\title{
PATENT ON NANOTECHNOLOGY IN INDONESIA AND ITS LEGAL CHALLENGE
}

\author{
Wahyu Yun Santoso* \\ Environmental Law Department, Faculty of Law Universitas Gadjah Mada, Yogyakarta \\ Jalan Sosio Yustisia 1, Bulaksumur, Sleman D.I. Yogyakarta 55281
}

\begin{abstract}
"A basis for the next technological revolution", could be the exact phrase to express the giant leap made with the development of nanotechnology, which is defined as a branch of engineering that deals with creating objects smaller than $100 \mathrm{~nm}$ in dimension. Challenges, in its own distinctive indeed, brought by nanotechnology to our social aspect, notably: (i) handling matter at the atomic scale means that qualitatively different behavior needs to be taken into account, and (ii) regarding to the use for humankind, introduces the problem of handling vast number of entities. This article aims to seek the answer the challenge lies before nanotechnology development in Indonesia: the Patent. To what extent national legal framework on patent could encounter this rapid development of nanotechnology. Further the article focusses on the legal framework needed to guarantee the patent for nanotechnology.
\end{abstract}

Keywords: nanotechnology, law, patent.

\section{Intisari}

"Teknologi berkembang secepat lompatan kuantum" mungkin bisa menjadi gambaran kondisi saat ini, ketika teknologi berkembang begitu cepat, sementara kerangka kebijakan tertatih di belakang. Belum selesai pembahasan bioteknologi, kita berjumpa dengan nanoteknologi sebagai "basis dari revolusi teknologi selanjutnya”. Nanoteknologi berkaitan dengan obyek yang berukuran lebih kecil dari 100 nanometer $\left(10^{-6}\right)$ dalam dimensinya. Tantangan hukumnya jelas menjadi sangat unik karena kekhasan karakter nanoteknologi, sementara itu tren perkembangannya di Indonesia juga cukup maju. Beberapa paten yang didaftarkan dan dimiliki oleh Mochtar Riadi Center for Nanotechnology sebagai contoh menunjukkan fakta hukum yang tidak dapat dikesampingkan begitu saja. Artikel ini bertujuan untuk mengemukakan satu isu terkait nanoteknologi di Indonesia, yaitu terkait paten. Pada jangkauan apa kerangka hukum nasional dapat beradaptasi dengan perkembangan yang pesat dari nanoteknologi ini. Selanjutnya artikel ini berfokus untuk memaparkan kerangka kebijakan untuk nanoteknologi di Indonesia.

Kata kunci: nanoteknologi, paten, kebijakan.

\section{Pokok Muatan}

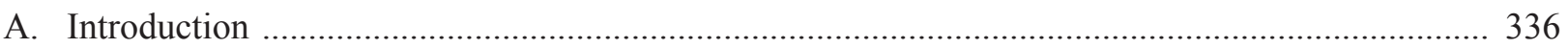

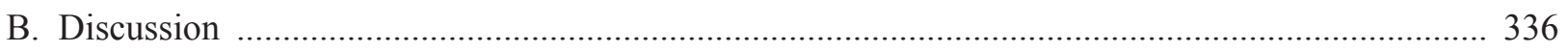

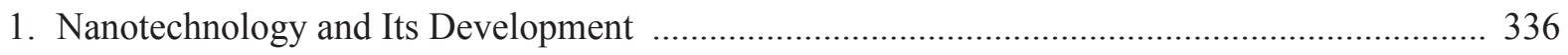

2. Concept of Patent Protection ............................................................................................. 339

3. Regulation Concept of Patent Concerning Nanotechnology ...................................................... 341

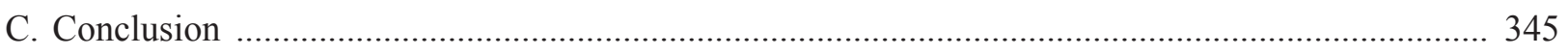

Correspondence address: wahyu.yuns@ugm.ac.id. 


\section{A. Introduction}

Nanotechnology is a science and technique of assembling and manipulating atom by atom or molecule with the purpose of creating a new world. Using nanotechnology, an object can be broken down to a plasma, then ionised to create a new form. Nanometer itself means one billionth of a meter, hence the technology is also related to the manufacturing of small objects. Nanotechnology is applicable in the development of technology in nanometer scale, normally 0,1 to $100 \mathrm{~nm}$. One nanometer equals to one thousandth of a micrometer or one millionth of a millimeter. ${ }^{1}$

Despite being a contemporary science at the time being, its swift leapt has left many questions that demand answer and resolution. Similar to other products of technology, nanotechnology has its own drawback and benefit to humans and their surrounding environment. The advantages of nanotechnology have been tested and proven in multiple fields, such as health, industry, nursery, beauty products, as well as in the effort of improving the environment.

One of the legal aspects related to nanotechnology is the matter of intellectual property rights over the technology itself. The regulation in regards to technological inventions is generally protected through Patent. As one of the aspects in intellectual property rights (Hak Kekayaan Intelektual or HKI), patent applies to provide protection for the inventors of nanotechnology. In Indonesia, the specific regulation concerning Patent can be found in Act No. 14 of 2001 on Patent.

Act No. 14 of 2001 on Patent contains a numbers of principles, namely (1) disclousure, (2) the granting of patent by virtue of request, (3) the duration of protection, (4) the obligation to perform Patent, (5) the rejection of registry in the interest of technology and economic development,
(6) the infringement on patent that constitutes as an offence warranting a complaint, (7) the use of priority rights, (8) territorial principle, etc. Through disclosure principle it is expected that new Patent will emerge as a development from the older ones and transfer of technology. At the moment, there is a tendency for Indonesian researchers, especially in the field of nanotechnology, to be more keen in in registering their Patent abroad, which hampers the transfer of technology. The example of patent of an Indonesian researcher on nanotechnology is a technology to measure the different responses of different medicines based on genetic analysis of multiple ethnics in Indonesia ${ }^{2}$ and method to diagnose liver cancer that is determined on the basis of its pattern or symptoms, ${ }^{3}$ registered on behalf of Mochtar Riyadi Institute of Nanotechnology Karawaci, May 2010 in Singapore and United States. Meanwhile, the protection of patent is rather significant to the concerning country in general and specifically to the development of the technology itself. The reason being, the protection of patent could become a source of income for the nation, in form foreign exchange since its development is deemed to have prospect.

\section{B. Discussion}

\section{Nanotechnology and Its Development}

Nanotechnology is a science and engineering in the manufacturing of material, structure, functional structure, as well as devices in nanometer scale. Within scientific terminology, nano means $10^{-9}(0,000000001)$. One nanometer equals to one thousandth of a micrometer, or one millionth of a millimeter, or one billionth of a meter. As comparison, a single piece human hair has diameter of 50.000 to $1000.00 \mathrm{~nm}$, therefore one nanometer roughly equals to a single piece of human hair divided by a hundred thousands. ${ }^{4}$

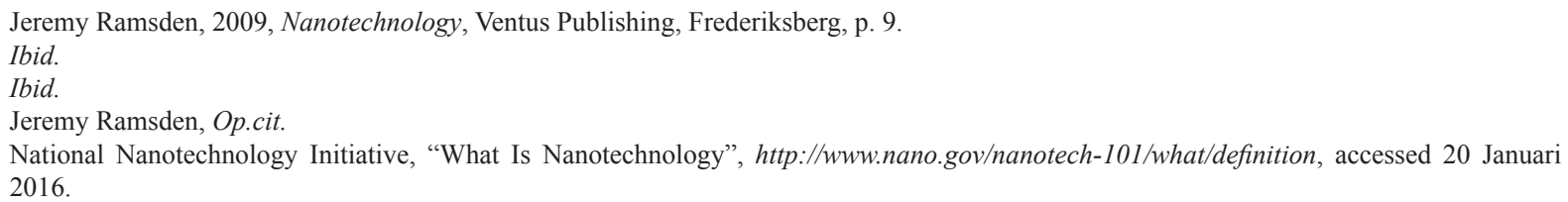


Richard Feynman, firstly introduced the concept of nanotechnology, ${ }^{5}$ in a scientific speech that was held by American Physical Society in Caltech (California Institute of Technology), on December $29^{\text {th }} 1959$, titled "There's Plenty of Room at the Bottom". While, the term nanotechnology was firstly formalised by Professor Norio Taniguchi from Tokyo Science University on 1974 in his papers, "On the Basic Concept of 'Nano-Technology". ${ }^{6}$

The subsequent development happened on 1980s, when the definition of Nanotechnology was further explored by Dr. Eric Drexler through his book "Engines of Creation: The Coming Era of Nanotechnology". " Nanotechnology itself is the fabrication and the utilisation of material in an extremely small size. This material is within the range of 1 to 100 nanometer $(\mathrm{nm}){ }^{8}$

Some institutions working on the field of technology and science research provide a definition for nanoscience and nanotechnology:

Nanoscience is the study of phenomena and manipulation of materials at atomic molecular and macromolecular scales, where properties differ significantly from those at a larger scale. Nanotechnologies are the design, characterization production, and application of structures devices and system by controlling shape and size at nanometer scale. ${ }^{9}$

Nanotechnology essentially employs an approach of technology in nano size. Ergo, there are two possible methods to enter the "Nano World", namely: ${ }^{10}$

a. Top-Down method: reducing bigger material to a smaller one; b. Bottom-Up method: assembling atoms and compound to form a bigger material.

"Top-Down" method is a method of formulating nano material through cutting or destructing bigger material, down to a nano size. ${ }^{11}$ Included in this category is lithography method as well as its modification method that is extensively used in computer chip production and various microelectronic devices. Whereas the second method "Bottom-up", is a technique that applies to arrange and manipulate atoms and molecule to nano size material. ${ }^{12}$ Among this method is positional assembly method that utilises certain auxilarry device to arrange atoms as the user wishes. However, this method is yet to be used for industrial purpose, due to its time consuming nature and the multi stages process involved. Where one stage can only be done subsequent to finishing the prior stage and its perfect success. ${ }^{13}$

Scientists are of the opinion that material in nano size has a numbers of chemical and physical characteristics that are superior to bulk size material. Material in nano size is also of a richer nature in characteristic, understanding that it produces some traits that are absent in bulk material.

Currently, the research on the field of nanotechnology has advanced rapidly and even entering into its most progressive stage in the recent years. The result of those researches, among others are: the manufacture of pill in nano size particle that could be controlled from outside of a body using electromagnetic wave, consequently allowing the pill to be controlled to attack the targeted disease

\footnotetext{
National Nanotechnology Initiative, "What Is Nanotechnology", http:/www.nano.gov/nanotech-101/what/definition, accessed 20 Januari 2016.

Norio Taniguchi, "On the Basic Concept of "Nanotechnology", Proceeding, International Conference on Production Engineering, Japan Society of Precision Engineering, Tokyo, 1974.

Luanne Tilstra, et al., 2008, The Science of Nanotechnology: An Introductory Text, Nova Science Publisher, Inc., New York, p. 4. Ibid.

Yateman Arryanto, et al., 2007, IPTEK Nano di Indonesia: Terobosan, Peluang dan Strategi, Deputi Perkembangan Iptek Kementerian Negara Riset dan Teknologi, Jakarta, p. 12.

Ibid.

Ibid., p. 14.

Ibid.

Ibid.
} 
without disrupting the other cell. ${ }^{14}$

The research done by Dr. Bruno De Geest, a chemist from Ghent University Belgia demonstrates an even more spectacular result, a tablet pill in nano size particle that is put into nano tube made from carbon and then combined with dextran gel coated with rigid permeable polymer membrane. ${ }^{15}$ When water from body tissue permeates into the nano tube, a grenade like explosion would occur, propelling the capsule to the targeted disease. The explosion of this nano grenade would accelerate the transmission of the medicinal material 800 times faster than the conventional method. ${ }^{16}$

One of the important nano materials nowadays is biomimetic material. Using Chemical Vapor Deposition (CVD), Lijie Zhang dan Thomas Webster in Nanotoday October 2009 Edition, ${ }^{17}$ have reported the use of titanium as biomimetic material to form a synthetic bone. The advantage to this material is its ability to associate with body cell without inflicting any side effect. The basic characteristic of titanium that is hard and stainless, allows its beneficial use as biomimetic material for humans. ${ }^{18}$

Due to is nano particle size that is extremely small in comparison to other body cells, nano particle could easily enter and exit human body without disrupting the bodily function of other cells. Cancer cell and normal cell have different chemical trait. When entering into normal cell and cancer cell, the particle will emit different luminescence light. By detecting the luminescence light, doctor could immediately detect the existence of the cancer cell in a body, its location, and size. ${ }^{19}$

Aside from its use in the aforementioned fields, nanotechnology is also incredibly useful for women. Nowadays, nano particle based cosmetics that benefit from the unique traits of nano particle are intensively studied. ${ }^{20}$ Big cosmetics companies have invested a large amount of fund to develop nano particle luminescence based cosmetics. Such investment allows for the possibility of developing cosmetics that are rich in colour.

Despite being a relatively recent, nanotechnology has offered a numbers of benefits. It is expected that a whole new innovation will come to the surface and brings about maximum benefits for mankind, although the risky it entails has become a problem of its own.

For so long the threat that may be caused from these particles of nanotechnology to human bodies has gained a focus of its own. Understanding the ever-present scientific uncertainty, scientists require years before they are able to fully comprehend the use of nanotechnology. Nano particle that is extremely small could, unbeknown, enter into a cell membrane, possible to carry a rather big foreign material, among others, is DNA helix..$^{21}$

There is yet a long-term medical research to this problem, however scientists have observed brain cancer on fish that consumed small amount of nano carbon particle. Rat that inhaled nanotube carbon suffered from complication in its lungs. Generally, nanotechnology experts are in the opinion that one should not worry about risk that nanotechnology may pose, however it still advised for general population to be cautious over the ability of nano particle to enter human body where other chemical particles cannot. ${ }^{22}$

TheUSFood andDrugsAdministration(FDA) on July 2010 has announced that drugs, cosmetics, and other consumer packaged goods that involved

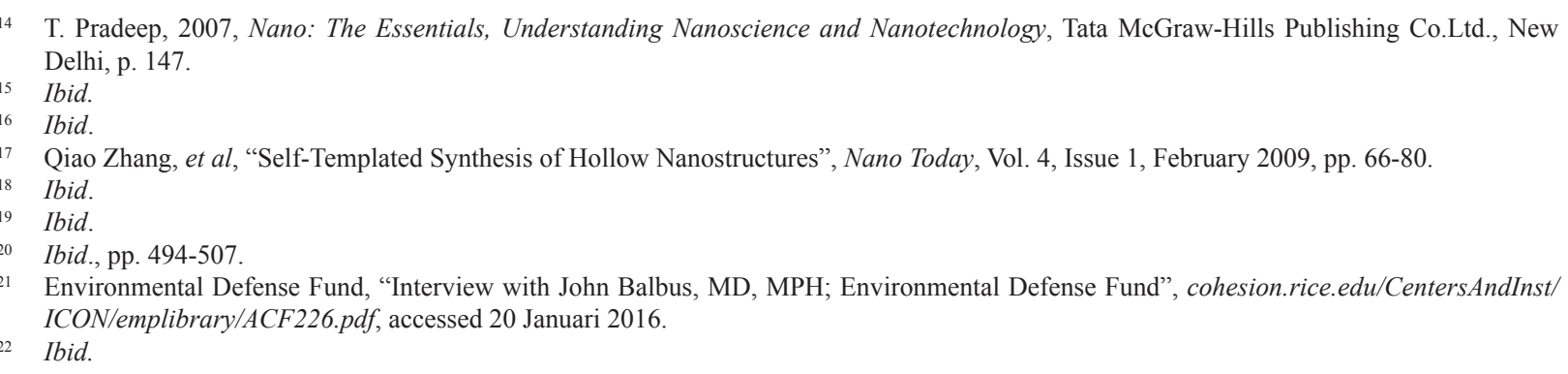


nanotechnology in its manufacture do not require specific regulation or labels since the FDA is in the view that there is no scientific evidence suggesting the safety risk of its application. ${ }^{23} \mathrm{~A}$ similar view is also held for the application of policies in regards to genetically modified products or foods. Such view is known as Generally Recognised as Safe (GRAS) policy. ${ }^{24}$ This policy is applicable by removing the necessity of a certain label for processed products involving biotechnology and nanotechnology insofar the existence of identical primary substance (substantially equivalent) of the products, both chemical and physical, could be proven. ${ }^{25}$

Reflecting the rapid development of nanotechnology in the world, Indonesia is in the ongoing process of developing nanotechnology of its own in multiple fields. The invention of multiple new nanotechnology based products evinces such development. However, room of improvement remains for the development of nanotechnology, understanding that Indonesia is yet to mature in applying the technology. In spite of that, the failure to develop nanotechnology based products in the upcoming future potentially causes domestic market becoming nothing more but targeted market for imported nanotechnology products, to the point where it is estimated that Indonesia suffers from the lost of value added amounting to $\mathrm{Rp} 10$ trillions per year.

MNI (Masyarakat Nano Indonesia) predicts that Indonesia needs at least $\mathrm{Rp} 4$ trillions in the next 10 years to stimulate research and development on nanotechnology so as to improving the competitive structure of national manufactured goods on the global stage. In light of this, Indonesia should immediately improve its development of nanotechnology, especially that Indonesia poses advantage that may become its own comparative advantage over other countries, namely its abundant natural resources that could be at its disposal for the manufacture of nanotechnology based products.

Generally, researches in the direction of nanotechnology have been done by a couple of research foundation or university and as well as Unit Litbang (research and development unit of Indonesia) from some ministries. Notwithstanding the quantity, its partial nature, along with its less than adequate facilities have slowed down the acceleration of research in the field of nanotechnology. Other problems that is deemed as a roadblock is the the problem of human resources, and the lack of thereof, aside from the severely minimum allocation of funding. On the stage of national policies, the direction of the development of nanotechnology aimed at improving national industry competitiveness, is yet to be formalised in detail and holistically. ${ }^{26}$ The concept of mastering and benefitting from nano Iptek (Ilmu Pengetahuan dan Teknologi, Bahasa Indonesia for science and technology) is a grand concept and requires government support, in terms of funding, regulation and monitoring, as well as evaluation. The absence of such support becomes the main obstacle in accelerating nanotechnology on national level. ${ }^{27}$

\section{Concept of Patent Protection}

Within the ambit of international trading, regulation concerning Patent that countries have agreed upon is Agreement on Trade Related Aspects of Intellectual Property Rights (TRIPS). Patent is of territorial nature within Trips, in a sense that the right is legally biding only in a specific location. ${ }^{28}$ As such, in order to benefit from Patent protection in

\footnotetext{
US Food and Drugs, "FDA News Release", http://www.fda.gov/NewsEvents/Newsroom/PressAnnouncements/ucm 258377.htm, accessed on 20 Januari 2016

24 African American Environmental Association, "Genetically Modified Foods", www.aaenvironment.com/GM.htm, accessed on 20 Januari 2016.

25 Mae-Wan Ho and Ricarda A Steinbrecher, 1997, Fatal Flaws in Food Safety Assessment: Critique of The Joint FAO/WHO Biotechnology and Food Safety Report, Physicians and Scientists for Responsible Application of Science and Technology (PSRAST), Penang.

26 Yateman Arryanto, "Peran RISTEK dan Arah Tema Riset Material Maju di Indonesia", Paper, Nanotechnology Seminar, Faculty of Engineering Universitas Gadjah Mada, Yogyakarta, 29 May 2011.

27 Yateman Arryanto, et al., Op.cit. p. 89.

28 Endang Purwaningsih dan Derta Rahmanto, "Perlindungan Hukum Terhadap Produk Nanoteknologi Melalui Hukum Paten", Jurnal Hukum Adil, Vol. 3, No. 1, 2012.
} 
some countries or regions, one has to submit patent application in each and one of those respective countries and regions. For European region, an individual may submit his/her Patent application to European Patent Office, if successful, applicant shall be granted multiple Patent (up to 36 Patent, each of them representing european countries), as opposed to one single patent for the whole region. ${ }^{29}$

The scope of Patent protection viewed from economic perspective relates to competition. Competition in the sense of: (1) competition where application of patent is based on first to file policy, implicating that the granting of patent to the first applicant excludes the possibility of another patent for similar inventions in the future. ${ }^{30}$ Similar policy applies to priority rights, should there be any applicants originating from countries applying priority rights based on Paris Convention, owner of similar inventions from the same countries shall be disqualified on the basis of filling date. ${ }^{31}$

The legal basis for the granting of Patent are as follow: ${ }^{32}$

1. As an incentive to create invention, patent becomes incentive for research and development activity to stimulate a development on technology and innovation.

2. As a reward for inventor for their invention that is beneficial for the development of technology and industry. Where it is deemed that it is only fair to reward inventors for all the hard work they put, that is time and financially consuming in inventing the new technology.

3. As a source on information, in the sense that with the existence of disclosure clause, and when an invention has been publicly announced, it shall be available for public use for continuous development and improvement to the point where improvement on the improvement is possible.

The purpose of patent, is specifically stressed on point three, where the granting of patent is intended to provide the availability of every inventions for public interest, for the sake of social benefit and technology development. By having an open access to information in regards to new invention, it is expected that such information shall serve as guidance for those who wish to develop and exploit prior art/invention.

An invention is an idea of inventor that essentially manifests into a problem solving process of a specific matter in the field of technology, in form of a product or a process, or an improvement and a development of product and process. Intellectual property rights in form of ideas and thoughts that are subject to legal protection shall contain patentable characteristics, i.e., novelty, applicability, and having incentive step. ${ }^{33}$

World Intellectual Property Organization $(\text { WIPO })^{34}$ provides the following general definition of patent:

A patent is legally enforceable right granted by virtue of a law to a person to exlude, for a limited time, others from certain acts in relation to describe new invention; the privilege is granted by a government authority as a matter of right to the person who entitled to apply for it and who fulfils the prescribed condition".

Essential element of patent can be studied by observing the definition above, that patent is an exclusive right granted by the government for certain invention. To acquire patent, an invention shall fulfill certain substantive prerequisites, i.e.

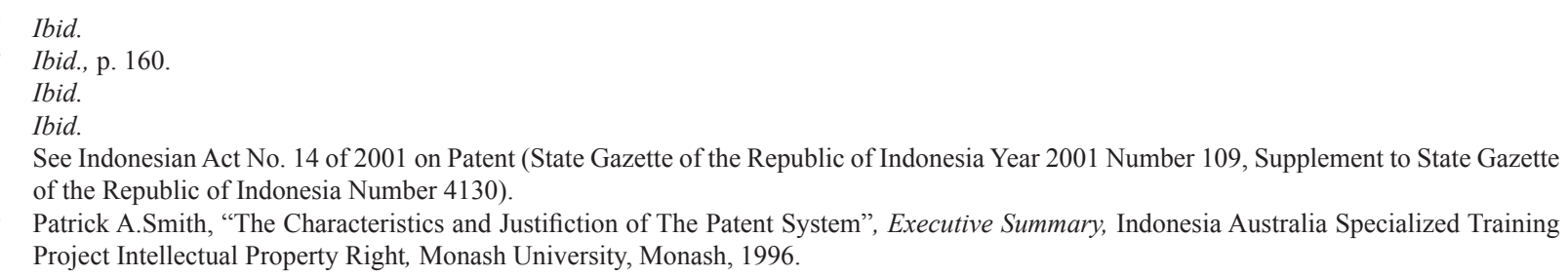

Patrick A.Smith, "The Characteristics and Justifiction of The Patent System", Executive Summary, Indonesia Australia Specialized Training Project Intellectual Property Right, Monash University, Monash, 1996. 
novelty, industrial applicability, having incentive step, as well as fulfilling formal prerequisites.

There are three major categories in regards to a patentable subject: process, machine, and produced and used goods. Process involves algorithm, business method, predominantly software, medical engineering, sports engineering and etc. Machine involves devices and apparatus. Processed goods include mechanical devices, electronic devices, and material composition such as chemicals, medicines, etc. ${ }^{35}$ Mathematical truth/logical truth falls beyond the category of patentable subject. So does software that applies algorithm unless there exist its practical application (in US) and technical effect (in Europe).

Currently, the problem of software patent (and business method) is a highly controversial subject. United States, in some legal cases, permit the use of patent for software and business method, whereas in Europe, software is considered as nonsubject to patent, although few inventions utilizing software remains patentable.

Patent related to natural substance (e.g., ones that could be found in wilderness) and medicines, as well medical treatment procedure, are all controversial subjects. In various countries, treatments to these subjects differ from one another. In United States for example, surgical procedure is patentable subject, yet the possibility to perform such right is excluded. ${ }^{36}$

Patent holder shall mean an inventor as owner of patent or recipient of such right from the owner of patent or a subsequent recipient of patent, who is registered in the general register of Patent. A patent holder shall have the exclusive right to exploit his patent and prohibit any other party who without his consent to: a. In the case of product-patent: makes, uses, sells, imports, rents out, delivers, or makes available for sale or rental or delivery of the patented product;

b. In the case of process-patent: uses the patented production process to make products and commits other activities as referred to in point a.

The following rights are the inherent rights attached to a patent holder: the right of a patent holder grant a license to other person on the basis of licensing agreement; the right of a patent holder to commence a lawsuit for damages through commercial court, against any person who deliberately and without rights committing actions in breach of his/her patent. ${ }^{37}$

\section{Regulation Concept of Patent Concerning Nanotechnology}

The Technical Guideline on Substantive Examination of Patent(Petunjuk Teknis Pemeriksaan Substantif Paten) released by the Directorate Patent Directorate General of Intellectual Property Rights Department of Law and Human Rights of The Republic of Indonesia (now referred as Ministry of Law and Human Rights of The Republic of Indonesia) stipulates that patentable invention should fulfill the following prerequisites: ${ }^{38}$

\section{a. Shall be in Form of an Invention}

Article 1 number (2) Act No. 14 Year 2001 on Patent states that an invention shall mean an inventor's idea that is poured in any problem solving activity in the field of technology, either in the form of a product or process, or an improvement and development of a product or a process. An invention is subject to limitation pursuant to its protection

\footnotetext{
35 Ibid.

36 Patent in relation to natural substance (such as ones that could be found in wilderness) as well as medicines, medical treatment procedure are all controversial subjects. In various countries, treatments to these subjects differ from one another. In United States, for example, surgical procedure is patentable, yet in practice such right has gained an opposition. Pursuant to Hippocratic Oath, a doctor is obliged to share his/her experience and expertise to his/her colleagues freely. Hence in 1994, The American Medical Association (AMA) House of Delegates submits a statement of objection to the application of such patent.

37 See Act No. 14 of 2001 on Patent (State Gazette of the Republic of Indonesia Year 2001 Number 109, Supplement to State Gazette of the Republic of Indonesia Number 4130).

38 Directorate Patent Directorate General of Intellectual Property Rights Department of Law and Human Rights of The Republic of Indonesia, The Technical Guideline on Substantive Examination of Patent.
} 
over its technical features. The technical guidelines further includes new variety of plants and animals, production process of plants or animals and plant products or animal products, should they be a result of essential biological process, biological process in this sense includes, but not limited to, the non involvement of technical intervention from humans. Including a technical process that is not a biological, yet essential to the production of plant or animal variety of an "invention".

Based on the explanation above, a request may contain subject matter that correlates with aforementioned products or process, as long as the claimed subject matter is still in connection with something that is deemed as patentable subject.

Ergo, an inventor's idea using nanotechnology as method to produce nano products could be used as problem solver in a specific field of technology, or an improvement and a development of a product or process that fulfills the requirements of patentable products.

\section{b. Shall Not be in Contradiction with Welfare and Interest of Society \\ Notwithstanding the fact that the} subject matter of a request is an invention, insofar it is harmful to the welfare and the interest of general public, such invention shall be rendered as non-patentable. Method of examination, medicines, medical treatments, surgical procedures, that are applicable for humans and animals. Access for society to medical treatments/drugs should not be restricted by a patent that allows its holder restricting others to perform such method. Nevertheless, products, especially substance/ compound used in the aforementioned method are not exempted from protection.
Including treatments for humans or animals, insofar it is non medicinal, nonsurgical, non therapeutic, and non diagnostic, remains subject to patentability, such as cosmetics for humans face, treatment to human body parts or dead animals, treatment to human body and animals (insofar the treatment does not apply for the same humans or animals) or treatment to stimulate growth for humans and animals.

Therefore, nanotechnology product that is in contradiction with welfare and societal interest is subject to patent, understanding it is not a product whose patentability is excluded.

\section{c. Shall be Susceptible of Industrial Application}

An invention shall come in form physical activity that derives from a technical feature, meaning that it should differ from a purely intellectual or artistic activity. This excludes product or process that is considered violating the established law of nature and physics in its operation. ${ }^{39}$

Nanotechnology product that comes as a result of bulk reduction carries a unique trait that is applicable in an industry based on the explanation above. This is further supported with the fact that nanotechnology products have been used in many sectors of industry.

\section{d. Shall be Novel}

An invention shall be considered as novel when its application filling date is not the same with any previous technological disclosure. Further in the Elucidation of Article 3 Paragraph (1) of Act No. 14 of 2001 on Patent, the technological terminology that was previously disclosed is "state of the art" or "prior art", that covers patent literature as well as non-literature patent. The definition of "not the same" in the aforementioned

39 Directorate Patent Directorate General of Intellectual Property Rights Department of Law and Human Rights of The Republic of Indonesia, The Technical Guideline on Substantive Examination of Patents. 
paragraph does not refer only to the matter of differences or distinction per se, rather on the differences on technical features of such invention in comparison to the technical feature of the prior invention.

The difference between nano products and bulk material that are identical is not limited to its dimension only, but as well as the differences in their characteristics, such as colour, capacity, flexibility, etc. These differences become strong consideration in determining the use of nanotechnology in industry. Nano products carry advantages that are absent in its bulk version.

\section{e. Shall Have Incentive Step}

An invention is deemed to have incentive step if it does not constitute as something that is obvious to a person with common expertise on specific engineering field. ${ }^{40}$ An object falls to the category of "something that is obvious" if it is acquired through logic from an already existing technology, which does not involve specific expertise, beyond what is normally expected by an expert. Expertise of an expert is knowledge that is gained through prior technology at the time of filling date, engineering field is an aspect to invention, however using a more complex invention experts are expected to collaborate in a group, in which they are expected to perform within that group, and able to utilise the expertise of his/her colleagues. ${ }^{41}$

The method of top-down and bottom up in nanotechnology are technology that was not obvious in the past, it required further research in determining materials that carry added value and superior traits to its bulk version and the suitable method to manufacture an applicable nanotechnology products. The combination of methods and selection of materials that are superior to its bulk result into nanotechnology that serves as problem solver in various specific fields.

\section{f. Shall Not Contradict Article 7 Act No. 14 of 2001 on Patent;}

Act No. 14 of 2001 on Patent contains articles concerning invention that shall not be granted with patent. There are 4 categories to it, namely any process or product of which the announcement and use or implementation contravenes the prevailing rules and regulations, religious morality, public order or ethics; any method of examination, treatment, medication, and/ or surgery applied to humans and/or animals; any theory and method in the field of science and mathematics; or all living creatures, except micro-organism; any biological process which is essential in producing plant or animal, except non-biological process or microbiological process.

Based on the preceding article, nanotechnology products do not specifically contradict the prevailing rules and regulation, religious morality, public order or ethics. Nano products carries unique trait to its size dimension and uniquely different to its bulk, however due to its wide array of substance and variety in function, this particular regulation does not easily apply on nanotechnology.

Concern has been raised ever since the formalization of Patent, along with the authority of "monopoly" that is granted to inventions, such concern comes from the parties that wishes to access the patented inventions. When a patent was firstly introduced to the public, generally the public was keen on knowing the creativity and novelty of that invention, and was in the consensus that the inventor was entitled of appreciation for his/her idea and for

40 Directorate Patent Directorate General of Intellectual Property Rights Department of Law and Human Rights of The Republic of Indonesia, The Technical Guideline on Substantive Examination of Patents.

41 See Elucidation of Article 2 Paragraph (3) Law No. 14 of 2001 on Patent (State Gazette of the Republic of Indonesia Year 2001 Number 109, Supplement to State Gazette of the Republic of Indonesia Number 4130). 
the willingness to share information regarding the invention. However at present, when the invention is popular and publicised, such perspective is less prevalent. The public starts to realise that the right to monopoly within patent fails to become an incentive to innovate, and to the contrary only serves as limitation for scientist to innovate using the license granted by the inventor.

Extra small size is of fundamental character within the concept of nanotechnology. Regardless, it is a popular belief to assume that the matter of 'nano' is merely about its size in dimension, and not substantive physical dimension. In the sense that, the novelty and the substantive differences are still subject to debate, whether or not it is suitable to attach them to the legal principle of patent. A factual evident to this occurred in 2005, when researchers or nanotechnology from Rice University announced its finding over "nanocars" that became subject to patent, a formation of 4 (four) "buckyball" 42 molecules connected by a "chasis" made from axylene axle. Problem arising from the matter of Patent focused on the question of the novelty of the invention, understanding the material used is basically common material in chemistry, except that they are reduced to "nanocars" form, albeit not demonstrating the common function of regular car. ${ }^{43}$

Patent consist of two principal components: written description of an invention and a set of document concerning claim. The claim is intended to be a specific statement (term, concept, and form) of an invention. In accordance with the perception that patent is a form of intellectual "right", it is normal to say that claim is a "survey" to ownership level. ${ }^{44}$ The survey explicitly states where the limitation to a "right" lies. Therefore, when an individual develops a product containing identical character/ trait or lies within the "sphere" of a claim, then it could be said that the individual has breached the limitation. Problem to this is the fact that the initial substance/term found in claim constantly changes in nature, meanwhile tracking to that changes requires specific technology.

A written description is intended to support an existing claim, so as to educating the public, in particular the parties to the concerning field of science about the detailed information regarding how to make and operate a particular invention. In United States, the description must include what is known as "best mode", or in other words the best way to apply and produce an invention.

Nanotechnology relates to a wide scope of scientific fields, understanding the term "nanotechnology" is an "umbrella term" that refers to (ownership) of every products and/or process in nanometre scale. From this, opportunity for change in novelty, irrespective of the field, on process or products, is incredibly high for potential patent of nanotechnology. This challenge becomes the foundation for European Union and United States for their regulation on nanotechnology. European Union through European Patent Office has added the obligation of inspection for nanotechnology products by three multidisciplinary experts, aside from providing special tagging system for nanotechnology products that ease its classification in the future. ${ }^{45}$

United States through the U.S Patent and Trade Office has also realised the crucial problem that hampers the matter of Patent for nanotechnology products. Firstly, special classification of nanotechnology patent allows for the possibility of a routine and constant tracking to the development of product and/or process of an already patented nanotechnology. ${ }^{46}$ Secondly, the minimum capacity and information of experts and examiners of

42 Buckyball is the popular name for buckiminsterfullerene, a group of atoms, in particular cabons, bonded and forming a circle/ball, tube, or ellipse. Buckyball was patented by researcher from Rice University for fullerene in form of a sphere (ball).

43 Patrick M. Boucher, 2008, Nanotechnology: Legal Aspects, CRC Press, New York, p. 8.

44 Ibid., p. 11.

45 Rana Gosain, 2005, Nanotechnology Patent Protection - Brazil and the World Market, Daniel Advocados Intellectual Property, Rio De Jenairo.

46 Raj Bawa, "Nanotechnology Patent Proliferation and the Crisis at the U.S Patent Office", Alabama Law Journal on Science and Technology, Vol. 7, 2007, pp. 699-735. 
nanotechnology products regarding prior art or prior invention. This is likely understanding nanotechnology is mainly a combination of multiple sciences that are interdisciplinary, except that it comes in smaller scale, thus prior invention or basic product could be a mere concept or even something that is incredibly scientific. ${ }^{47}$ Furthermore, the concept of "monopoly" over Patent causes uncertainty of sources that would trigger problem for parties that deliberately "conceal" their referral sources for competition reason. ${ }^{48}$ For these two main reasons, U.S Patent and Trade Office since 2005 has been on an aggressive ongoing effort to conduct structural reformation of its organisation as well as updating its documentation system and postpublication classification. ${ }^{49}$

United States as the country with the most patented nanotechnology products begins altering its perception over patent claim concept from "how to make" to "how to use". This shift on perception, the regulation framework of Patent becomes more transparent to nanotechnology products. In the sense that process, not limited to the how to make process but also including make-use process, become the focal point of new invention, instead of focusing only on the product. Through an enhancement on evaluation and Patent classification, it is expected that this Patent system would be able to bridge the wide gap of invention level on the field of nanotechnology.

The final question to be submitted is: What about Indonesia? The current legal framework of Patent in Indonesia is pursuant to TRIPS-WTO standards. Based on the previous analysis on prerequisites and general regulation on Patent, it could be said that the current patent system allow for patent over nanotechnology products. However, the main problem is rather on the instruments to enforce and the availability of human resources. By examining the general problem surrounding patent for nanotechnology products, as has been discussed above, the existence of a proper, integrated, and clear system of classification and tracking becomes an absolute necessity. It is also necessary to have a consensus in regards to whether or not nanotechnology is a mere miniature from an already existing product with differences on size without any substantial distinction, ${ }^{50}$ or the opposite to that opinion. Aside from that, a comprehensive, precise, and interdisciplinary evaluation system for Patent registry is also needed. Such necessities are just the beginning, the succeeding matter would be on the post registry protection by the state.

\section{Conclusion}

Based on the analysis and discussion above, several conclusions could be drawn, and at the same time become answers to the problems identified in this research, namely: First, the concept of legal protection specifically on the instrument on patent could be applied on the development of nanotechnology. This is in line with what has been done by several other countries, for example the United States and Japan. However, a uniform opinion among regulators and Patent examiner in Directorate General of Intellectual Property Rights Department of Law and Human Rights of The Republic of Indonesia is needed, that nanotechnology does not merely concern physical size dimension, but also differences in characteristics that are formed by the differences in the dimension. This opinion is necessary so that the result of nanotechnology products could fulfill the prerequisites of novelty and incentive step, all in all to satisfy the requirement of patent. Additionally, a proper tracking and classification, and protection

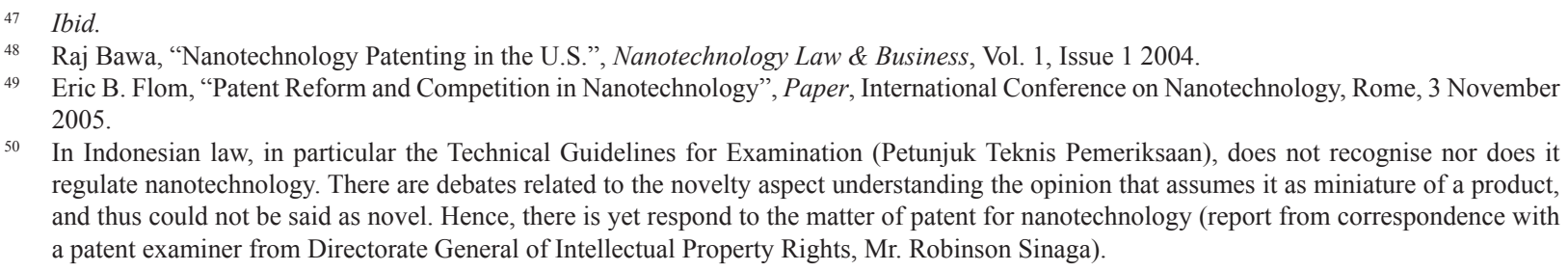

50 In Indonesian law, in particular the Technical Guidelines for Examination (Petunjuk Teknis Pemeriksaan), does not recognise nor does it regulate nanotechnology. There are debates related to the novelty aspect understanding the opinion that assumes it as miniature of a product, and thus could not be said as novel. Hence, there is yet respond to the matter of patent for nanotechnology (report from correspondence with a patent examiner from Directorate General of Intellectual Property Rights, Mr. Robinson Sinaga). 
system, post registry protection is an obligation for the state to fulfill, including a comprehensive, precise and interdisciplinary evaluation system.

Second, the field of nanotechnology has undergone a sufficient level of development in Indonesia, albeit not as splendour as other technology. This is evinced through the conduct of several researches in some research institutions and universities as well as "Unit Litbang" (research and development unit of Indonesia) from several ministries. However, its partial nature and its less than adequate facilities and infrastructure become roadblock to the acceleration of researches in the field of nanotechnology. Other problem that remains prevalent and deemed as an obstacle is the inadequate numbers of human resources related to nanotechnology, aside from the problem of minimum funding. On the level of national policies, the direction of nanotechnology to stimulate national industrial competition is yet to be formulated comprehensively and in detail, from the regulation aspect of HKI (law on intellectual property rights) concerning nanotechnology as an object, and the mechanism to track the product of nanotechnology. This particular reason becomes the underlying problem for the acceleration of nanotechnology on national level.

Third, the national legal framework of patent and "HaKI" (law on intellectual property rights) in general has accommodated the possibility of patent instruments for the product of nanotechnology. Regardless, the underlying problem remains due to the basic character of nanotechnology, it's extremely small size. The problem of size is merely focused on physical dimension in size, but yet on substantive physical dimension. In the sense that, there are still pros and cons regarding the novelty of nanotechnology products. The existing concepts in some countries believe that nanotechnology products have no novelty and substantive different at all to the prior art. In Indonesia, such opinion that nanotechnology is a mere miniature of an already existing object is significantly prevalent as well. This becomes one of the reasons, and as well as the factor hampering the fulfillment of patent prerequisites. Although, in actuality the key lies on the unreadiness of government official to perform assessment over patented nanotechnology products. In addition to the absence of a proper mechanism to ensure that the registered nanotechnology actually satisfies the requirement as provided in Patent regulation. Some considerations, aside from size aspect, like any other distinction level, novelty, and assurance that the product is indeed new, and not available previously, become issues to be considered in discussing the concept of legal protection on Patent for nanotechnology products in Indonesia.

\section{REFERENCES}

\section{A. Books}

Arryanto, Yateman, et al., 2007, IPTEK Nano di Indonesia: Terobosan, Peluang dan Strategi, Deputi Perkembangan Iptek, Kementerian Negara Riset dan Teknologi, Jakarta.

Gosain, Rana, 2005, Nanotechnology Patent Protection - Brazil and the World Market, Daniel Advocados Intellectual Property, Rio De Jenariro.

Ho, Mae-Wan and Steinbrecher, Ricarda A., 1997, Fatal Flaws in Food Safety Assessment:
Critique of The Joint FAO/WHO Biotechnology and Food Safety Report, Physicians and Scientists for Responsible Application of Science and Technology (PSRAST), Penang. Ramsden, Jeremy, 2009, Nanotechnology, Ventus Publishing, Frederiksberg.

Pradeep, T., 2007, Nano: The Essentials, Understanding Nanoscience and Nanotechnology, Tata McGraw-Hills Publishing Co.Ltd., New Delhi. 
Tilstra, Luanne, et al., 2008, The Science of Nanotechnology: An Introductory Text, Nova Science Publisher, Inc., New York.

\section{B. Journal Articles}

Bawa, Raj, "Nanotechnology Patenting in the U.S.", Nanotechnology Law \& Business, Vol. 1, Issue 1, 2004

Zhang, Qiao, et al., "Self-Templated Synthesis of Hollow Nanostructures", Nano Today, Vol. 4, Issue 1, February 2009.

\section{Internet}

African American Environmental Association, "Genetically Modified Foods", www. aaenvironment.com/GM.htm, accessed 20 Januari 2016.

Environmental Defense Fund, "Interview with John Balbus, MD, MPH; Environmental Defense Fund", cohesion.rice.edu/CentersAndInst/ ICON/emplibrary/ACF226.pdf, accessed 20 Januari 2016.

National Nanotechnology Initiative, "What Is Nanotechnology", http://www.nano.gov/ nanotech-101/what/definition, accessed 20 Januari 2016.

US Food and Drugs, "FDA News Release", $\mathrm{h} t t p: / / w w w . f d a . g o v / N e w s E v e n t s / N e w s r o o m /$ PressAnnouncements/ucm $258377 . \mathrm{htm}$, accessed 20 Januari 2016.

\section{Paper}

Flom, Eric B., "Patent Reform and Competition in Nanotechnology", Paper, International Conference on Nanotechnology, 3 November 2005.

Arryanto, Yateman, "Peran RISTEK dan Arah Tema Riset Material Maju di Indonesia", Paper, Nanotechnology Seminar, Faculty of Engineering Universitas Gadjah Mada, Yogyakarta, 29 May 2011.

Taniguchi, Norio, "On the Basic Concept of "Nanotechnology"”, Proceeding, International Conference on Production Engineering Japan Society of Precision Engineering, Tokyo, 1974.

Smith, Patrick A., "The Characteristics and Justifiction of The Patent System", Executive Summary", Indonesia Australia Specialized Training Project Intellectual Property Right, Monash University, Monash, 1996.

\section{E. Regulations}

Law No. 14 of 2001 on Patent (State Gazette of the Republic of Indonesia Year 2001 Number 109, Statute to State Gazette of the Republic of Indonesia Number 4130).

Directorate Patent Directorate General of Intellectual Property Rights Department of Law and Human Rights of The Republic of Indonesia, The Technical Guideline on Substantive Examination of Patents. 